\title{
Policy Suggestions on the Transformation and Development of Local Undergraduate Colleges and Universities
}

\author{
LI Na \\ Shandong Xiehe University \\ Jinan, 250100, China \\ Lina0704@126.com
}

\begin{abstract}
The transformation and development of local universities is the basic requirement of the society for the training of talents in higher education. Through the discussion of the problems in the development of local undergraduate colleges, the paper puts forward policy proposals for transformation and development: Establishing the position of applied technology university in China's higher education system, and strengthening theoretical research on the training of applied technology talents; Strengthening the policy guidance and macro guidance for the transformation and development of local undergraduate colleges and universities; Establishing a scientific and standard classification evaluation system and increasing the funding for the university of applied technology; Establishing modern university system and implementing autonomy in running colleges and universities; International cooperation in applied technology universities under the national framework.
\end{abstract}

Keywords-Local colleges; Transformation and development; Policy suggestion

\section{INTRODUCTION}

Outline of the national medium and long term talent development plan (2010-2020 years) points out: The world is in the period of great development, change and adjustment. Along with the multi-polarization world, the deeply developing of economic globalization, the changing of science and technology and the ascendant of knowledge economy, the development of talent is a major strategic choice to win the initiative in the fierce international competition. Higher education bears the important task of training highlevel professional talents, developing science and technology culture and promoting socialist modernization. Therefore, the development of higher education is closely related to social progress. Higher education can influence and restrict the development of the country's economy and society through personnel training.

At present, China's higher education has entered the stage of mass development, and the scale of higher education ranks first in the world. According to the investigation, the problem of college students' employment is very difficult, and the employment problem of college graduates is serious year by year, and many enterprises are difficult to find a large number of applied technical talents. This phenomenon shows that there is a big gap between the graduates and the needs of the society. On the one hand, the supply of talents is oversupply, and on the other hand, the large demand for talents cannot be satisfied.

The main problem is not the number of personnel training, but the misplacement of the talent supply and demand in the personnel training specifications, which leads to the structural unemployment of college graduates, and the institutional roots come from the existing structure of higher education.

Higher education and social development are closely linked. The structure and function of higher education reflect the characteristics of the higher education system from two aspects of internal and external relations. When the relatively stable structure within the higher education system cannot effectively interact with the external environment, higher education cannot play its due role in the social system, that is, the imbalance in the ability of higher education. From a realistic point of view, the structural unemployment of college students reflects the imbalance of the external relations between higher education and social political economy, cultural tradition and science and technology. And the imbalance of the external relationship will directly affect the internal of higher education, which requires higher institutions to make corresponding changes in the aspects of training objectives, professional settings, curriculum structure, teaching mode and so on, according to the requirements of social and economic science and technology. In a review of the experience of educational reform in developed countries, British scholar Paule said: "to adjust educational goals to adapt to the new pressure and new social needs, the main way of education is to reform the educational structure."[1] "The outline of the national medium and long term education reform and development plan (2010-2020 years)" clearly suggests that "adapt to the needs of national and regional economic and social development, establish dynamic adjustment mechanism, and constantly optimize the structure of higher education. We should focus on expanding the training scale of applied, compound and skilled talents." 


\section{PROBLEMS IN THE DEVELOPMENT OF LOCAL UNIVERSITIES IN CHINA}

The structural adjustment of higher education is not only related to the reform of macro structure, but also to the adjustment of microstructure.

The micro structure of higher education refers to the composition state and connection of the institutions of higher learning, including administrative structure, subject structure, curriculum material structure, teacher team structure, and personnel knowledge structure. If the school's micro structure is unreasonable or unbalanced, it will directly affect the quality of personnel training and restrict the development of schools.

The local undergraduate colleges and universities refer to the provinces, autonomous regions and municipalities directly under the central government, mainly with local financial support, and undertook the ordinary undergraduate colleges and universities for the local (industry) training of talents and services. The newly established undergraduate colleges refer to the newly established undergraduate schools since 1999.

From the present situation of higher education in China, the difficult employment of college students and the shortage of industrial enterprises will reflect the difficulties and obstacles in the employment of students and the economic development of higher education services. Statistics show that local colleges and universities have low employment rate, low professional counterparts, and low quality of employment, in particular, the new universities that have been established since 1999. The local universities are the main force of mass higher education in China because of their largest number, the largest enrollment and the largest number of trained personnel. At present, it is in a dilemma of development and presents the following outstanding problems and contradictions in the whole higher education system: One contradiction is between the school evaluation system based on academic standards and the applied technology university based on the accumulation of technological innovation and the actual contribution of the service industry. The contradiction between professional structure based on discipline system and setting up majors according to the occupation and post needs applied technology universities. The contradiction between teacher system based on academic qualifications and the construction of a "double qualified" teacher team and flexible employment system. The contradiction between enrollment system for college entrance examination, stratified admission and expansion of students with skills and continuing education for developing careers. The contradiction between internal governance structure of education that is relatively closed and the industry enterprises of the university of applied technology that are directly involved in the governance [2]. The contradiction between internal operation mechanism based on knowledge teaching and seamless docking based on real application. And so on. Although many local colleges and universities are working hard to develop, and they have made great achievements, but the local colleges and universities have fallen into a dilemma because of the unreasonable classification of the higher education, the single evaluation system, the unified allocation method.
The development of local undergraduate colleges has its own insurmountable difficulties. Combined with China's current economic and social development of talent demand and employment status of college students, The transformation and development of some local colleges and universities is not only the realistic choice for the development of colleges and universities, but also the key to the promotion and development of the higher education in the adjustment of the national economy. Therefore, the transformation of local universities has become the focus of structural adjustment of higher education. From the experience of developed countries, the structural adjustment of higher education is to optimize the macro structure of higher education. Through the adjustment of the matching degree of higher education and social and economic development, it can effectively activate the service function of education to the economy and give full play to the important role of education in promoting the national competitiveness.

\section{POLICY SUGGESTIONS ON THE TRANSFORMATION AND DEVELOPMENT OF LOCAL UNDERGRADUATE COLLEGES AND UNIVERSITIES}

The innovative practice of applied technology university will play a vital role in establishing a modern vocational education system and enhancing the competitiveness of the real economy [3]. The establishment of applied technology universities in developed countries is realized by government led, active participation of industry and enterprises, and active transformation and development of schools. Therefore, the transformation and development of local undergraduate colleges and universities in China is not a simple addition to the single reform measures, nor a simple rename, but a comprehensive and systematic reform. We must clarify the objectives and standards of transformation and development, and promote substantive reform and innovation in transitional universities.

\section{A. Establishing the position of applied technology university in China's higher education system, and strengthening theoretical research on the training of applied technology talents}

The establishment of colleges and universities is the source. According to the requirements of the classification management of colleges and universities, the classification of colleges and universities should be put into practice, and the classification settings should be changed from the hierarchical setting (junior college education, institute and university) to the classification settings. According to the outline of the national medium and long term educational reform and development plan (2010-2020 years), we should establish a classification system for colleges and universities and carry out classified management. We should give full play to the role of policy guidance and resource allocation, guide the rational orientation of colleges and universities, overcome the tendency of homogeneity, form their own ideas and styles, and create the characteristics at different levels and different fields and strive for the first class. Therefore, in the adjustment of the structure of higher education in China, the applied technology university is regarded as an important component 
part of the national higher education, and it is equal to that of the ordinary university [4].

The purpose is to explore laws, innovate theories, guide practice and service decisions. Gather the resources of all sides and integrate the wisdom of experts to play the role of the applied science and technology university (college) alliance and the Ministry of education's educational science decision research center. A special study on the transformation and development of local universities and the training of applied technology talents should be carried out to better play the role of theory based on practice and service guidance practice. The university of applied technology should help the Ministry of education to do a good job in the transformation and development of local universities and to establish the research, consultation and guidance of the university of applied technology, to ensure that the government's public decision-making has a more extensive social foundation, embodying scientific, foreseeable and transparent, so that the transformation and development of local universities have been made more and more important. With a broad scientific foundation, it embodies the advanced nature, feasibility and effectiveness.

\section{B. Strengthening the policy guidance and macro guidance for the transformation and development of local undergraduate colleges and universities}

The Ministry of education should introduce the guiding opinions on the transformation and development of local universities as soon as possible, and establish the system of government leading, industry guidance and enterprise participation, and establish the incentive and promotion mechanism for the sustainable development of the combination of production, learning and research. First of all, under the guidance of the Ministry of education, the local government will coordinate the development of industrial industry and establish the departments of education, human resources, reform and statistics [5]. It is responsible for the concrete organization and implementation, the path of pilot and gradual promotion, and the model and experience through the pilot. Secondly, we should guide the industry personnel to participate in the Education Guidance Committee of the University of applied technology, and play a role in major policy research, the monitoring of talent supply and demand, professional qualification, employment access, school enterprise cooperation, professional setting and evaluation, curriculum and teaching material development, personnel training mode reform, education quality evaluation and so on. Finally, at the legal level, we should clarify the social responsibility of enterprises in personnel training and promulgate educational legislation and encouragement policies that are conducive to the establishment of a deep mechanism of industry university research cooperation.

The participation of industry and enterprises in school enterprise cooperation is the characteristic of talent training in applied technology universities. Governments at all levels provide legal, regulatory and institutional safeguards for industry enterprises to participate in cooperative education. One is to formulate laws and regulations or related policies, guide or request enterprises to enter colleges and universities, strengthen the consciousness and social responsibility of cooperation and education between enterprises and universities, and promote both the win-win situation of school and enterprise. The second is to transform the functions of local educational administration departments, serve schools and enterprises more, and become the bridge link between schools and enterprises.

\section{Establishing a scientific and standard classification evaluation system and increasing the funding for the university of applied technology}

In accordance with the requirements of the national medium and long term educational reform and development plan (2010-2020 years), we should establish a scientific and standardized assessment system. Introduce the evaluation system and evaluation system in line with the characteristics of applied technology talents training and applied technology universities. For example, the evaluation standard of the undergraduate teaching level of applied technology, the accreditation and evaluation standard of applied technical talents training (professional group) and the evaluation standard of the subject construction of applied technology university. Establishing a quality evaluation mechanism for social participation in talent training and encouraging specialized agencies and social intermediaries to evaluate the quality and level of applied technology universities. Guiding the transformation and development of local undergraduate institutions through classified evaluation [6].

The University of applied technology emphasizes the practical teaching, the requirements of hardware conditions are high, the cost of training must be higher than that of other types of colleges and universities, and the local universities have not set up a benign mechanism for the local economic construction of personnel training and service, and the financing channels are few. Therefore, governments at all levels should give the applied technology universities certain policies and financial support. One is to select pilot institutions for transformation, and the central and local governments to set up special funds for transformation and development of local undergraduate universities, giving special support to pilot Universities in transition. The second is to change the current mode of financial allocation to universities, and determine the standard of financial allocation according to the type of schools. The third is to formulate laws and regulations that encourage enterprises to invest in education, and support enterprises to participate in higher education. 
D. Establishing modern university system and implementing autonomy in running colleges and universities

Expanding the right of professional setting of applied technology university, under the guidance of educational administration departments and industries, and guided by local economic development. According to the demand of the local leading industry and technology field, on the basis of the current undergraduate course catalogue, the specialty of the professional catalogue and the mechanism of professional dynamic adjustment and timely response are set up independently.

Expand the school to introduce the autonomy of teachers. According to the needs of the training of applied technical talents, teachers should be introduced autonomously. We should change the existing quota system for professional titles, so that teachers who have strong engineering practice ability and outstanding applied research achievements will have equal promotion opportunities. Attract more high-level engineers, technicians and technical experts to enter universities or parttime jobs in schools. Schools should establish a "double qualification" teacher training system, and guide teachers to practice regularly and improve their engineering practice ability.

Reform the recruitment examination system. Changing from a single assessment and source of students to a variety of sources and checking ways. We should explore diversified enrollment and recruit secondary and vocational school graduates individually. The national skill competition winners should be excused from an examination. We should encourage industries, enterprises and applied technology universities to cooperate to recruit students, and establish the system and mechanism from secondary vocational, undergraduate and doctoral graduate students, and build a "cross bridge" of the cross and parallel life-long education of common education and vocational and technical education.

\section{E. International cooperation in applied technology universities under the national framework}

The international cooperation of applied technology university " $1+1$ " is one of the important contents of the transformation and development of local undergraduate colleges and universities. It is an important means to promote the transformation and development of local undergraduate colleges and universities. It is a new field of international cooperation and exchange in the field of education in China, and also an important part of establishing strategic cooperation relations with European countries. Therefore, it is a state behavior, not a school's spontaneous behavior. It needs overall design and advancement from the national level. Under the leadership of the Department of planning of the Ministry of education and the international exchange and cooperation department, we should recommend the subject and the professional group of the cooperative schools in accordance with the local government, and establish the cooperation between the universities of applied technology and the schools

\section{CONCLUSION}

China has entered the stage of popularization of higher education. Therefore, higher education adapts to the development of economic society and satisfies the aspirations of the people to accept more and better education. It is imperative to adjust the structure of higher education. The local universities should break the traditional thinking mode and school mode, look at the present higher education with a new perspective, make fundamental changes to the national needs of the transformation and development, serve the goal of the local social and economic development, and bear the social responsibility and historical task endowed by the society.

\section{ACKNOWLEDGEMENT}

Author: Li Na, female, born in 1980, Master, associate professor, mainly engages in human resource management and enterprise strategic decision. Email:lina0704@126.com. Tel: 13573766354

\section{REFERENCES}

[1] Zhang Xiaoyue. Multidimensional structure and influence mechanism of academic participation of Chinese University Students[J]. Fudan Education Forum, 2012 (6). (In Chinese)

[2] Guo Jianru. Core issues in the transformation and development of Local Universities [J]. Journal of Huanghe Science and Technology College, 2017(1). (In Chinese)

[3] Zhong Binglin, Wang Xinfeng. Analysis of the path of transformation and development of local ordinary undergraduate colleges in China [J]. Higher education research, 2016(10). (In Chinese)

[4] Ye Xiaoyang, Ding Yanqing. Expanded Chinese Higher Education: educational quality and social stratification[J]. Society, 2015(3). (In Chinese)

[5] Zhu Hong, Chen Xiaoyu, Bao Wei, Xiong Yu. The cultivation of higher science talents from the perspective of students: Problems and challenges [J]. Teaching in Chinese universities, 2015 (6). (In Chinese)

[6] Ma Liping, Guan Qingtian. Evaluation of college level and student capability increment: Based on an empirical study of 85 universities in China [J]. Education development research, 2016 (1). (In Chinese) 